\title{
PIK3CG Gene
}

National Cancer Institute

\section{Source}

National Cancer Institute. PIK3CG Gene. NCI Thesaurus. Code C24673.

This gene is involved in cell adhesion, signal transduction and maintenance of the structural and functional integ rity of epithelia. 